\title{
Territorial Disputes in the South China Sea: Possible Solutions Ahead
}

\author{
Pinki Maurya
}

Assistant Professor, Lakshmibai college University of Delhi, New Delhi, India

Corresponding author: pinkimaurya7@yahoo.com

Received: 15 Sept., 2021

Revised: 25 Nov., 2021

Accepted: 17 Dec., 2021

\begin{abstract}
South China sea is a strategic sub region of the Indo-Pacific which has significant economic and commercial importance. It is bordered by South East Asian countries which makes its location geo strategically significant. There are issues related to the territorial disputes by the stakeholders claiming the territorial sovereignty within the region and throughout the Indo-Pacific. In the recent years china has increased its efforts to assert its territorial claims over the sea by encroaching the Islands or creating new Islands. US claims that sovereignty in the area should be determined by UNCLOS as it is international water. The major obstacle in resolution of the issue is China's insistence on conducting its diplomacy on a bilateral basis. Arbitration mechanisms suggested by the International Tribunal for the law of the sea is also rejected by the China. Region's increased militarisation has made the dispute more difficult to resolve. There is a need to initiate confidence building measures and dispute management mechanism with all the countries involved to prevent further escalation of problem.
\end{abstract}

Keywords: Territorial sovereignty , territorial disputes, stakeholders, international water, International tribunal for the law, dispute management mechanism, confidence building measures.

Territorial and Jurisdictional disputes in the South China Sea continues to simmer conflict between China and other Countries of the Southeast Asia. Brunei, China, Malaysia, Philippines, Taiwan and Vietnam have their overlapping territorial claims in the South China Sea. Claimant states have stakes in retaining the rights to fishing areas and exploration of crude oil and natural gas in the sea. The

How to cite this article: Maurya, P. (2021). Territorial Disputes in the South China Sea: Possible Solutions Ahead. Learning Community, 12(02): 155-164. 
P Maurya

importance of South China Sea lies in the fact that nearly 11 billion barrels of oil and 190 trillion cubic feet of natural gas reserves are under the sea according to United States Energy Information Agency. Trade route through South China Sea has the greatest value for countries. According to a 2015 Department of Defence Report, \$5.3 trillion worth of goods moves through the sea every year, which is about 30 percent of global maritime trade. That includes huge amounts of and $\$ 1.2$ trillion worth of annual trade with US.

\section{Issues in the South China Sea}

The most contentious territories of South China Sea to which all of the six major Southeast Asian nations lay claims are Spratly Islands, Paracel Islands, Pratas Islands, Macclesfield Bankand and Scarborough shoal. As these Islands are mostly uninhabited, so sovereignty becomes an issue to contest by all the stakeholders.

Each Country has an Exclusive Economic Zone (EEZ) according to United Nations Convention on the Law of the Sea (UNCLOS) of 1982, over which these claimant countries have special rights to marine resources and energy exploration. China's spat with Vietnam in December 2012 over the area of EEZ reinstated the fact that these zones also come under controversies related to sea.

Another contentious issue related to South China Sea is the demarcation line called "Nine-Dash Line" used by China over the Scarborough shoal and the Paracel and Spratly Islands to claim as its territories. This line is contested by the ASEAN countries in 2009 when China submitted a map to UN which included the demarcation. It drew the international criticism and opposition. China has insisted on the historical legitimacy of the demarcated line by referring fishing activities and naval patrols since the fifteenth century.

United States claims that the sovereignty in the area should be determind by the United Nations Convention on Laws of the Sea (UNCLOS), as it is international water. In the recent years China has increased its efforts to assert its territorial claims over the sea by encroaching the islands or creating altogether new islands. China has constructed ports, stationed military and has been piling sand onto existing reefs of sea. These activities of China continues to strain relations between China and other countries of Southeast Asia which could risk a military escalation. Southeast Asian Countries have competing claims on various zones and islands, such as Spratly islands, which possess rich natural resources and fishing areas.

China asserts that under international law, foreign militaries are not able to conduct intelligence gathering activities in its Exclusive Economic Zone (EEZ). According to United States, countries should have freedom of navigation through EEZs in the sea and are not required to notify claimants of military activities.

To contest China's claims in South China Sea, US has been occasionally deploying destroyer ships to ensure freedom of navigation for maritime passages to facilitate trade and the movement of naval forces. China has challenged and warned concerned Southeast Asian Countries for drilling oil and gas 
in the seabed of the contested region. US commercial and strategic interests in the region have resulted in expressing its support for taking confidence building measures and setting a binding code of conduct through Agreement. The global rivalry of China, US and Southeast Asia over the sea could undermine international laws governing maritime disputes.

China claims the "Nine Dash Line", which is the largest portion of territory of sea falls entirely within its territory. UNCLOS determines the maritime zones on coastlines. US which is a signatory of UNCLOS often refers it to settle territorial disputes. Southeast Asian countries have also urged China to abide by the UNCLOS, but China invokes intertemporal laws based on the historical record to maintain its claim in the sea.

For China UN maritime governance laws are incompatible with its domestic laws. China views the interference of US in the region as its emergence as a global power which has western hegemonic dimensions. At times there are low level skirmishes between Chinese naval patrols and civilian fishermen from neighbouring countries which can anytime result into major international conflicts. In July 2017, a five judge panel in The Hague rejected the legal claims of China in the sea. Despite that, after some time China's Supreme People's Court issued a regulation in which China has all legal basis to safeguard maritime order in the sea. It further stated that China can prosecute any foreigners found fishing or doing any activity in the diputed waters.

So legal means of settling complex territorial disputes, even through the Southeast Asian Nation's Association have appeared to be ineffective. US does not take an official positon on South China Sea disputes, but criticizes China's expansionist policies in the sea. It plans to expand defence alliances against China with other Southeast Asian Countries that have overlapping claims. By 2021, US Navy officials plan to expand the pacific fleets overseas assigned forces by approximately 30 percent.

\section{Recent Trends in the Policies}

Recently China has proposed a new national park in the South China Sea. This has again escalated tensions between Asian rivals over the disputed waters. NPC deputy and party chief of Hainan Tropical Ocean University Wang Chagren interviewed in Global Times, "A national park in the region can improve people's awareness of the region's importance and the South China Sea should be a textbook for maritime protection in China."

Southeast Asian countries have been claiming that through these activities China is developing its military capabilities in the region by building infrastructure on the sea.

In a ruling of the International Court in 2016 China's island building was criticized for causing severe harm to the coral reef environment. Similarly in 2017, China opened a cinema in Sansha on the paracel islands, which are claimed by Vietnam and Taiwan. Besides building land reclamation projects and artificial islands, China has been constructing airstrips and ports, which are suspected to be used for military purposes. US also alleges that the island building projects of China can obstruct the navigation within the disputed area. 
Trump administration has not taken any concrete action so far in the South China Sea dispute, as observed by the media. There are speculations that because US wants China to get along on the North Korea issue, Trump administration is putting all other interests on one side at the moment.

US commitment to counter China's growing influence in the region seems to be little uncertain in the Trump's administration. Although American Policy towards South China Sea has been consistent since the late 1990's. The then Secretary of State Hillary Clinton mentioned in a meeting of ARF in 2010, that the US would not get involved in any territorial disputes. The South China Sea problem must be discussed in main regional forums such as the ARF, East Asia Summit and the ASEAN meeting. China has been maintaining its stand for bilateral negotiations with each of the relevant countries for the possible solution. It has always refused to internationalize the issue.

The United States has provided support to Philippines on the issue of encroachment of Spratly Islands by China. However US takes serious care in not getting involved militarily in the event of the conflict in the South China Sea. American Strategic approach to the South China Sea is in maintaining a strong military presence in the region in order to maintain access to the ocean and to limit the China's supremacy. American Navy is positioned in the sea to promote an international rules based order, where the right of the countries to have free transit and free trade is not infringed upon.

Members of the ASEAN Countries expect the trade of US in strengthening the security system in South China Sea. The member countries of ASEAN rely on UNCLOS as a means to pursue their own interests and oppose China's aggressive approach.

In November, 2017, the leaders of China and the ASEAN Countries have formally endorsed the framework for a Code of Conduct $(\mathrm{CoC})$ to find a solution of overlapping territorial claims in the South China Sea. The Code of Conduct for the South China Sea intends to prevent violent conflict in the most strategic maritime area (Lee 2017).

Adoption of a CoC was stipulated in 2002 in Article 10 of the Declaration on the Conduct of Parties in the South China Sea. According to Declaration all parties should exercise self-restrain with regard to activities that can escalate disputes in the region. It asked to refrain from taking any action of inhabiting on the presently uninhabited islands, reefs and other features.

ASEAN Secretary General Le Luong Minh in an interview, indicated that 2002 Declaration on Conduct has not been effective and all the claimants have carried out construction and oil exploration in disputed areas. So, ASEAN Countries view that $\mathrm{CoC}$ must be made a legally binding instrument.

Tracing the roots of South China Sea dispute, before 1960's, other claimants of the dispute did not respond to China's claim of most of the part of the sea. With the exploration of reserves of oil and natural gas after 1960's, China and other ASEAN Countries started counter challenging the claims of ownership of the parts of South China Sea.

Severe military conflict took place between China and Vietnam in the 1970's. Constant military conflict took place between the claimant countries from the period between 1970's and early 1990's due to 
lack of trust and communication. With the end of the cold war, in the late 1990's several agreement were signed between China and Vietnam to settle the territorial dispute. On the other hand the tension between China and Philippines started brewing up. Philippines involved the US by signing the visiting forces agreement between the Philippines and US in 1998 to counter the power of China. ASEAN Countries coordinated their policies for South China Sea to counter the authority of China in the sea.

In 2002 claimants signed Code of Conduct on the South China Sea and China also joined the Treaty of Amity and Cooperation in Southeast Asia in 2003 to reach on some kind of official consensus for the resolution of the issue.

The Code of Conduct stipulated that dispute should be solved in accordance with international laws. All the claimant countries found it wise to restrain from escalating the dispute and to build confidence building measures for the possible solutions. However, there are several factors which act as impediments, for the final and all actors acceptable solution. China does not accept any compromise on the territory issue, keeping in view its domestic politics. The issue of nationalism in the domestic politics of China would affect the legitimacy of Chinese government at home. Similar limitations are faced by other claimant countries too. In recent years sovereignty issue has gained momentum so much that major actors involved in the dispute, refrain touching upon it. Another issue is of finding the process of negotiations and discussions acceptable to all the stakeholders. China does not believe in multilateral negotiations and strongly oppose the making of issue an international dispute. On the other hand ASEAN Countries prefer the multilateral dialogue and involvement of US to balance the superiority of China in the region.

Despite the differences in the methodology of creating peaceful environment, all the major stakeholders want to establish peace in the region. With the spread of globalization and increasing interdependence of world economics, claimant countries want to cooperate with each other for mutual benefits. Regional economic cooperation is also gaining importance with the establishment of a Free Trade Area between China and ASEAN . Regional economic interdependence between stakeholders have reduced the chances of confrontation.

In May 2017 China also released a white paper on vision for maritime cooperation under the Belt and Road Initiative. The central point of the paper is concerned with the concept of common maritime security. Because of militarization of islands and reefs by Chia claimant Countries are skeptical about the white paper. China's rejection of judgment of permanent court of Arbitration in 2016 has impacted the trust factor with its claimant countries. It has built four new missile shelters in disputed islands in the sea and violated international norms.

At number of times China has shifted its position on the principles of territorial sovereignty and international norms. In some of its official declaration likes its paper on China's policies of Asia Pacific Security of January 2017, there is adherence to the principles of the charter of United Nations, UNCLOS, International Laws and modern maritime laws. Strategically, there is no mention of UNCLOS in the joint communique of DRI of May 2017. The ambiguities in the policies of China on South China Sea make it less trustworthy. 
China has also been able to divide the ASEAN members with its policy of economic gains and initiating development projects through the instrument of BRI. China extended loan to Cambodia to combat its debt crisis and because of the economic aid given by China, some of the ASEAN members are adopting relatively neutral stand on the issue.

The region's increased militarization because of China's expansionist policies has made the dispute more difficult to resolve. Vietnam and Malaysia have also build ups military and arms trade with Russia and India in order to protect their interests. Philippines also doubled its defence budget in 2011 and started five year joint military exercises with the US.

\section{Path Towards Peace}

The major obstacle in resolution of the issue is China's insistence on conducting its diplomacy on a bilateral basis. International tribunals like the International Tribunal for the Law of the Sea and United Nations also provided mechanisms for arbitration, which are rejected by the China.

ASEAN has attempted at times to reach on a conclusion to mitigate the conflict. Six point statement was issued in 2012 to outline an agreement for regional code of conduct and to self-restrain of countries involved Consequently joint management of resources was proposed by the experts to ease out current tension. China and Vietnam have agreed to cooperate and work on a common fishery zone in the Tonkin Gulf. However oil exploration is a major contentious issue as both Vietnam and Philippines have started oil exploration projects with foreign companies in the disputed areas (Thayer 2013).

Experts observe that Southeast Asia has transformed in the last two decades to an area where Chinese power and strategic ambition confront an established US military presence and Chinese perception of South China Sea is at odds with major maritime states.

There is a need to initiate confidence building measures and dispute management mechanism with all the countries involved to prevent further escalation of the problem. Efforts are required for better implementation of the existing declaration on the Conduct, which is acceptable to all. Joint exploration of natural resources through multilateral cooperation mechanism can prove fruitful for mutual benefits.

In view of some experts, legal solution to settle the issue would be long lasting. Through legal solution, all claimant countries can take resort to International Court of Justice for arbitration. International Court of Justice can judge the dispute by applying international laws acceptable to all parties. Another view is adopting a political solution, where all the concerned parties can discuss the issue in formal meetings either through bilateral or multilateral dialogue at various levels.

Further it is suggested that confidence building measures can adopt two tack strategies such as the workshop approach or having joint project in disputed areas for energy exploration. Joint projects for natural resources exploration combined with formal and informal meetings can develop confidence and understanding among various stakeholders (Singh 1999). Stability and security of the South China Sea is very important for the development of countries involved in the issue. 
The primary step required to stabilize the region, would be to demilitarize it, which was reflected in the will of concerned countries in passing the declaration on the Conduct of Parties in the South China Sea in 2002. ASEAN Regional Forum can play more vibrant role in providing ideas and suggestions to solve the issue and provide a platform for the communication of all the stakeholders. As the Realist theory of international relations suggest that states act rationally and avoid conflicts, the concerned countries would enhance understanding and cooperation in order to fulfill their national interests.

There are other issues that complicate the Maritime Agreements in the South China Sea. The politics of maritime boundary making laws restricts effective governance of the China Sea. Various negotiators involved are reluctant to compromise on the principle of sovereignty over maritime space laws. Claimant countries also find it difficult to determine whether EEZs, should coincide with continental shelf boundaries. Different opinions are expressed on this depending on the state of the bilateral relationship between the neighbouring countries.

Overlapping jurisdiction is possible in case of sound relationship with the neighbour country, otherwise it is unlikely to achieve the basic level of cooperation and developing understanding with the concerned country. Generally, there is a trend to have coincident EEZ boundaries and continental shelf. This is not always possible so countries adopt separate boundaries for continental shelf and EEZs. For example, Indonesia and Malaysia have agreed on a continental boundary of the Natuna Islands, but not agreed on a common EEZ boundary. Similarly, Indonesia and Vietnam have agreed on a continental shelf boundary but no common EEZ boundary.

Bordering countries will have to broaden their horizons from the issue of sovereignty, which is a test of their nationalism and sole ownership of resources, to reach on some consensus for solution of the issue. An extended functional cooperation and joint management is the need of this hour. Experts also observe that a web of provisional arrangements covering cooperation for different functions and for different areas is needed. Joint development of oil and natural gas resources, marine safety methods, joint marine scientific research for the protection of marine environment, common fisheries management are some areas where claimant countries can have mutual overlapping common interests.

The recent announcement by Philippines President Duterte of the Scarborough Shoal as an environmental marine sanctuary could prove to be the first positive step towards the resolution of the South China dispute. Analysts observe that taking a less confrontational approach with China by Philippines, can secure an economic aid from China. The balance of power in the South China Sea dispute has prevented an armed conflict among the claimant states.

China has moderated, although some of its tactics on South China Sea, but still it continues to seek greater control over the sea and airspace. It is also noteworthy that dispute of various attempts to persuade China to control its expansionist policies, Chinese programs of land reclamation and land encroachment have not come to a halt. China has rejected Philippines attempt to resolve its territorial dispute through arbitration under UNCLOS. While remaining neutral on the issue of sovereignty, US can pressurize China to curtail its policies of expansionism. US can play a larger role in encouraging all nations to pursue their claims peacefully and in accordance with the international law. 
There is also a suggestion, that US can encourage ASEAN to develop its own draft of CoC including a dispute resolution mechanism which can be acceptable to China also. US can extend its assistance to ASEAN Countries to enhance their security capabilities to deter Chinese interference. Under UNCLOS Article 123, the 1982 law of the sea convention demands that when state parties are involved in a dispute in enclosed or semi-enclosed seas they should "endeavor, directly or through an appropriate regional organization to coordinate the management, conservation, exploration and exploitation of the living resources of the sea and also to coordinate their activities" with respect to the protection and preservation of the marine environment.

Mark Valencia has observed that: "Indeed when countries in Asia think maritime, they think first and foremost about boundary disputes, not protection of the deteriorating maritime environment or management of dwindling fisheries". In these kind of situations binding legal laws are the best possible means to settle the dispute (Valencia 2008).

ASEAN Counties are willing to settle disputes among themselves in accordance with UNCLOS. ASEAN has been holding a number of conferences and meetings to discuss the disputes in South China Sea and agreed to resolve issues peacefully under the guidance of UNCLOS and international law. Minh Vu, observed that "one should not overlook the Philippines-Vietnam-Malaysia-Indonesia strategic cooperation. These four states can develop and adopt a common position on various aspects of the law of the sea in the South China Sea. For ASEAN, operating in the context of a regional power shift, normative and legal approaches were and will remain the most feasible solution when dealing with stronger nations."

In a recent meeting with ASEAN Naval forces US proposed the Joint Patrol Force in the South China Sea to carry out cooperative patrols in the South Sea. US has also proposed the establishment of a South China Sea International Operations Centre in Indonesia. Jakarta was proposed as it has constantly expressed its willingness to mediate the disputes between China and ASEAN members.

US proposals reflect its cooperative strategy to manage regional security threats. Policy papers of US since 2007 also reflect the initiatives for adopting multilateral approaches for cooperative security. Ely Ratner observes, Increasing security threats and instability in the region are largely due to misinformation, misperception and mismanagement of the states involved. He observes: "the lack of Maritime Domain Awareness (MDA) in the South China Sea is an endemic problem that has strategic and operational consequences. Countries in the region remain insufficiently equipped to monitor their near seas, creating an environment prone to accidents, miscalculation and adventurism.

In the absence of an effective conflict mechanism and MDA in the South China Sea, regional stability, maritime security and national security of the countries involved is at stake. South China Sea Monitor and South China Sea Threat Index were created to deal with the security threats by building regional maritime threat awareness. The SCS Monitor and SCS Index are important platform for policy makers and academicians to discuss and provide suggestions for strengthening the security of the region. Current security status is depicted through these indexes to analyze the situation of peace and conflict in the region. Even in past attempts were made throughout the 1990s to prepare the ground for conflict resolution. Unofficial series of annual workshops were organized by Indonesia with the funding of 
Canada. Despite annual workshops organized by Indonesia during the period 1990-1998, success of these efforts were very limited as the outcome. The intention behind the organization of workshop was to initiate collaborative projects and to reformulate the regional agendas.

Till the present date, the conflict on the issue of sovereignty remained unsolved and still dominates the public discourse on regional security talks. Even after ten years of track II diplomacy, the major issues in the course of negotiations remain same. Talks and diplomacy have been succeeded to a limited extent. Thus a resolution of the conflict presuppose a combination of bilateral and multilateral talks with the increased interference by the International Court of Justice. Although an informal multilateral framework has initiated to involve experts from various domains to resolve the issue, still no clear trend towards the solution is visible.

The situation in the South China Sea has been relatively stable in the recent times. Experts view the situation as maintenance of 'status quo' in the region. As there is no concrete trend towards violent conflict or solution of issue. The question of sovereignty is still in stalemate and claimant states are avoiding taking a stand on it. There is a continuous effort to improve bilateral relations between some of the states with stakes in South China Sea.

Recently, claimant countries involved in the dispute have stepped up mutual communication to prevent the escalation of conflict. High level official talks have been initiated in between China and Vietnam, and China and Philippines which comprise most of the conflicts of region. In August 2017, China and the members of ASEAN agreed to adopt a framework for a Code of Conduct in the South China Sea. This is viewed as a new beginning in easing and resolving disputes in the region. India also urged for peaceful solution to the disputes in the sea as the stability in the region is necessary for the safety of the shipping routes. Minister of state of for External Affairs V.K. Singh said in a meeting in Laos that "the sea lanes of communication passing through the South China Sea are critical for peace, stability, prosperity and development." India supports freedom of navigation based on the principles of international law.

A political and legal solutions through negotiations and meetings of the major stakeholders can lead towards the establishment of peace in the region. Interference by the US, Japan, Australia and India have also exerted pressure on the claimant states to find a peaceful solution of the conflict. US is seeking to maintain its dominance in the Asia-Pacific by its interference in the region.

Given the complex nature of the territorial and maritime disputes of the South China Sea, experts have suggested the principle of joint development of resources and the principle of joint protection of environment. In areas with multiple claimants, it is generally agreed that not only negotiations, but managing the natural resources jointly can prove very effective as an interim solution for managing the dispute. Philippe Sands observes that sustainable development demands states to ensure the development and use of their natural resources through cooperative actions, which would be beneficial for all the stakeholders. Joint protection mechanism can be utilized to build confidence and to promote trust among claimant states. 
P Maurya

Peaceful South China Sea is a need not only for the stakeholders involved but also for the whole international community as South China Sea is a common heritage of all the states.

\section{REFERENCES}

1. Abhyankar, M.R. 2018. Beyond strategic autonomy : Indian diplomacy Oxford university press.

2. Burgess, S. 2020. Confronting china's maritime expansion in the South China sea, The Journal of Indo-pacific Affairs, 3(3).

3. Carlyle, A.T. 2013. New commitment to a code of conduct in the south china sea, The national bureau of Asian research.

4. Cheung, T.M. 1990. Growth of Chinese naval power, priorities, goals, missions and regional implications, Institute of south east Asian studies, Singapore.

5. Fenton, M. 2021. Analysing the causes and effects of the south china sea dispute. Journal of Territorial and Maritime Studies, 8(2).

6. Gordon, K. 1966. The dimensions of conflict in South East Asia, New Jersey, Prentice Hall.

7. Joshi, M. 2016. The south china sea disputes: Territorial claims geopolitics and international law ORF occasional papers.

8. Kuoklynn, 2019. How china's actions in the south china sea undermine the rule of law Global China.

9. Lee, Y. 2017. A south china sea code of conduct : Is real progress possible. The Diplomat.

10. Prasad, S.B. 2021. Rivalry in south China sea. Shodhshauryan, 4(3).

11. Rajagopalan, R.P. 2021. Contering Chinese assertiveness : India's changing posture in the Indian ocean ORF.

12. Regilme, F. 2018. Beyond paradigms : Understanding the South China sea dispute using analytic eclecticism, 55(3).

13. Singh, R. 1999. Investigating confidence building measures in the Asia pacific region. Stimson report.

14. Tran Truong and Jener, C.J. 2016. South china sea :A crucible of regional cooperation of conflict making sovereignty claims. Cambridge university press.

15. Valencia, M.J. 2008. A maritime security regime for north East Asia. Asian Perspective, 32(4). 